\title{
ANALISIS PENGGUNAAN MODEL THINK, TALK AND WRITE BERBANTUAN VIDEO PADA MAHASISWA DISABILITAS
}

\author{
Etriana Meirista ${ }^{1)}$, Mitra Rahayu ${ }^{2)}$, Karlina Wong Lieung ${ }^{3)}$. \\ ${ }^{1}$ Fakultas Keguruan dan Ilmu Pendidikan, Universitas Musamus Merauke \\ email: etriana@unmus.ac.id \\ ${ }^{2}$ Fakultas Keguruan dan Ilmu Pendidikan, Universitas Musamus Merauke \\ email: rahayu.mitra23@gmail.com \\ ${ }^{3}$ Fakultas Keguruan dan IImu Pendidikan, Universitas Musamus Merauke \\ email: lieung@unmus.ac.id
}

\begin{abstract}
This research is based on findings in the field regarding the existence of children with special needs in the regular classrooms where researchers teach. Students with special needs in the class show symptoms of forfeit and difficult to blend with normal friends in general in class. The situation that occurs is that students with special needs are very enclosed in class, not actively participating in lectures. The independence of students in doing assignments is very low. The existence of an inclusive education curriculum motivates researchers to continue to be able to provide educational services for all students without exception. Students with disabilities referred to in this study were one deaf student and one speech impaired student. This study will describe the independence and motivation of student learning in the classroom with the application of the cooperative model Think Talk and Write (TTW). The research method uses descriptive analysis. Data collection techniques by observation, interview and documentation. The collected data is then analyzed qualitatively including data reduction, data presentation and drawing conclusions. The results showed that the independence and motivation of student learning tended to be good with the active role of the teacher in applying the appropriate learning model. The communication difficulties that existed among students in the class were successfully overcome by the active role of all students in working together in discussion groups.
\end{abstract}

Keywords: hearing impaired, speech impaired, independence

Abstrak: Penelitian ini didasari atas temuan di lapangan mengenai keberadaan anak berkebutuhan khusus di kelas reguler tempat peneliti mengajar. Mahasiswa berkebutuhan khusus di kelas tersebut menunjukkan gejala menarik diri dan sulit berbaur dengan temanteman normal pada umumya di kelas. Keadaan yang terjadi adalah mahasiswa berkebutuhan khusus tersebut sangat tertutup di kelas, tidak berpartisipasi aktif dalam perkuliahan. Kemandirian mahasiswa berkebutuhan khusus dalam mengerjakan tugas sangat rendah. Adanya kurikulum pendidikan inklusi memotivasi peneliti untuk tetap dapat memberikan layanan pendidikan bagi seluruh mahasiswa tanpa terkecuali. Mahasiswa berkebutuhan dimaksud dalam penelitian ini adalah satu orang mahasiswa tuna rungu dan satu orang mahasiswa tuna wicara. Penelitian ini akan mendeskripsikan kemandirian dan motivasi belajar mahasiswa di kelas dengan penerapan model kooperatif tipe Think Talk and Write (TTW). Metode penelitian menggunakan analisis deskriptif. Teknik pengumpulan data dengan observasi, wawancara dan dokumentasi. Data yang terkumpul kemudian dianalisis secara kualitatif meliputi reduksi data, penyajian data dan penarikan kesimpulan. Hasil penelitian menunjukkan bahwa kemandirian dan motivasi belajar mahasiswa cenderung baik dengan adanya peran aktif guru dalam mengaplikasikan model pembelajaran yang sesuai. Kesulitan komunikasi yang ada diantara mahasiswa di kelas berhasil diatasi dengan peran aktif seluruh mahasiswa dalam bekerja bersama dalam kelompok diskusi.

Kata kunci: tunawicara, tunarungu, motivasi, kemandirian 


\section{PENDAHULUAN}

Pembelajaran inklusi sudah dilaksanakan secara meluas sejak diberlakukannya Permendiknas No. 70 Tahun 2009. Sistem pendidikan inklusi menyediakan layanan pendidikan bagi anak berkebutuhan khusus di sekolah reguler (Garnida, 2015:61). Penyandang disabilitas diartikan setiap orang yang mengalami keterbatasan fisik, intelektual, mental, dan/atau sensorik dalam jangka waktu lama yang dapat berinteraksi dengan lingkungan dapat mengalami hambatan dan kesulitan untuk berpartisipasi secara penuh dan efektif dengan masyarakat (RI, UU no 8. 2016). Kelainan atau gangguan yang dialami seringkali menghambat penyandang untuk dapat berpartisipasi aktif di lingkungan masyarakat (Lestari, 2016:104). Oleh karena itu, berbagai cara dilakukan agar anak berkebutuhan khusus dapat memiliki kemandirian dalam kegiatan apapun. Begitu pula dalam segi pendidikan formal, khususnya dalam tingkat perguruan tinggi yang selanjutnya akan dsebut dengan mahasiswa berkebutuhan khusus (MBK). Mahasiswa berkebutuhan khusus adalah mahasiswa yang memiliki keterbatasan fisik, intelektual, mental, sensorik, dan/atau yang memiliki potensi kecerdasan dan bakat istimewa (RI, Permenristek dikti No 46. 2017). MBK memerlukan layanan pendidikan yang sesuai, setidaknya demi tercapainya kemandirian bagi penyandang. Salah satu kategori MBK yang sering dijumpai di universitas penyelenggara pendidikan reguler atau inklusi adalah kategori MBK tuna rungu dan tuna wicara.

Tuna rungu merupakan suatu kondisi dimana terdapat kelainan pada indera pendengaran yang menyebabkannya sulit berkomunikasi dengan orang lain (Anassyah \& Shodiq, 2016: 140). Tunarungu sering kali dianggap sebagai kelainan yang paling ringan. Padahal, segala prinsip "kelainan atau kehilangan" pasti memiliki dampak yang cukup besar bagi para penyandang (Lestari, 2015: 274). Permasalahan yang sering dialami oleh penyandang tunarungu yakni dalam hal komunikasi dan sosialisasi (Wasito, dkk. 2010: 139). Tunarungu diklasifikasikan menjadi lima kategori berdasarkan tingkatannya yaitu: ringan (kehilangan pendengaran antara 27-40 dB), sedang (kehilangan pendengaran antara 41-55 dB), agak berat (kehilangan pendengaran antara 56-70 dB), berat (kehilangan pendengaran antara 71-90 dB) dan sangat berat (lebih dari $90 \mathrm{~dB}$ ) (Wardani, dkk. 2012).

Tunawicara merupakan suatu kondisi dimana seseorang mengalami gangguan dalam berkomunikasi secara ujar atau lisan (Awaluddin, 2016: 95). Tuna wicara diklasifikasikan menjadi empat kelompok diantaranya keterlambatan bicara (speech delay), gagap (stuttering), kehilangan kemampuan berbahasa (dysphasia), dan kelainan suara (voice disorder) (Purwanto, 1998). Kesulitan berkomunikasi tentunya menghambat seseorang dalam berinteraksi dan bersosialisasi dengan lingkungannya (Mahmud, 2016). Seseorang yang menderita kegagapan hingga dewasa seringkali merasa rendah diri dan sulit bersosialisasi.

Permasalahan komunikasi dan sosialisasi berimbas pada permasalahan lain yakni motivasi serta kemandirian belajar. Kesulitan mahasiswa dalam berkomunikasi dengan orang lain di kelas seringkali menyurutkan motivasi belajar pada dirinya. Mahasiswa dengan gangguan berkomunikasi juga memiliki kemandirian yang rendah dalam kegiatan perkuliahan sehingga seringkali tertinggal dalam hal akademik.

Kesulitan yang dialami MBK tentu saja harus ditangani dengan baik oleh dosen. Ada beragam model pembelajaran dan cara yang dapat digunakan dalam membantu layanan pendidikan MBK di 
kelas reguler. Salah satu model pembelajaran yang dapat digunakan yaitu model kooperatif tipe Think Talk and Write (TTW) yang dikombinasikan dengan media atau metode tertentu. Model pembelajaran tipe TTW yang berbasis assesment for learning melalui penilaian teman sejawat memperoleh hasil belajar yang lebih baik pada kategori kemandirian belajar tinggi (Asy'ari, 2016). Model pembelajaran ini pun bila dibantu menggunakan media video, memperoleh hasil belajar yang baik pada kategori tinggi (Juniardi, M.A., Parmiti, D.P., dan Dibia, I.K. 2017). Model TTW merupakan model yang dirancang untuk meningkatkan aktivitas belajar. Pada pelaksanaannya, mahasiswa tuna rungu dan tuna wicara dikelompokkan dengan mahasiswa lain di kelas. Hal tersebut diharapkan mampu merangsang jalinan komunikasi dan sosialisasi yang baik diantara seluruh mahasiswa.

Aktivitas mahasiswa dapat ditingkatkan melalui tahapan berpikir (think), berbicara (talk) dan menulis (write). Pada tahap berpikir, mahasiswa akan diberikan suatu tayangan pemaparan materi dan suatu kasus yang merangsang keterampilan berpikir dalam memahami dan menemukan solusi atas permasalahan yang ditayangkan. Mahasiswa selanjutnya diarahkan untuk dapat mengungkapkan kembali materi serta solusi dihadapan anggota kelompok diskusinya serta temanteman di kelas tahap ini kemudian disebut tahapan talk. Kegiatan ini dimaksudkan melatih keberanian serta kemampuan mahasiswa tuna rungu maupun tuna wicara (gagap) untuk tampil berbicara di depan umum. Selama proses perkuliahan, mahasiswa akan mencatat hal-hal penting berkaitan dengan materi yang sedang dibahas (write).

Model TTW akan membantu mahasiswa tuna rungu dan tuna wicara dalam memahami materi, mengatasi masalah komunikasi dan sosialisasi di kelas serta media video pembelajaran membantu mahasiswa untuk dapat memahami materi dari yang ditayangkan dalam video. Penerapan metodologi pengajaran dan penggunaan teknologi sangat penting dalam pendidikan inklusi karena MBK menukai kelas partisipatif dan aktif dengan mempertimbangkan karakteristik MBK itu sendiri (Gavira, dkk. 2016).

Penelitian ini dilakukan untuk melihat implementasi penggunaan model think, talk, write berbantuan video pada mahasiswa disabilitas sesuai dengan karakteristik yang dimiliki pada pendidikan inklusi.

\section{METODE PENELITIAN}

Penelitian ini mengimplementasikan model pembelajaran TTW dengan bantuan video yang telah dibuat sendiri sesuai dengan karakteristik mahasiswa disabilitas di kelas inklusi. Langkah-langkah pembelajaran model pembelajaran tipe TTW berbantuan video yaitu:

1. Dosen menjelaskan cara belajar menggunakan model pembelajaran kooperatif tipe TTW.

2. Dosen menyampaikan tujuan pembelajaran.

3. Dosen membentuk kelompok mahasiswa yang terdiri dari 3-5 mahasiswa dan menunjuk salah satu mahasiswa dari tiap-tiap kelompok untuk menjadi ketua kelompok.

4. Dosen menyampaikan materi pembelajaran dengan menggunakan bantuan video pembelajaran.

5. Mahasiswa memperhatikan tayangan video pembelajaran yang ditampilkan dan membuat catatan kecil secara individu tentang apa ang diketahui. Ketika mahasiswa membuat catatan kecil maka terjadi proses berpikir (think) pada mahasiswa. 
6. Mahasiswa berinteraksi dan berkolaborasi dengan teman satu kelompok untuk membahas isi catatan kelompok dari hasil catatan individu (talk).

7. Dari hasil diskusi dalam tahap talk, mahasiswa merumuskan pengetahuan berupa jawaban atas masalah dalam bentuk tulisan (write).

8. Dosen membagikan LKM yang memuat soal yang harus dikerjakan oleh mahasiswa dan mahasiswa menyelesaikan soal tersebut.

9. Dosen meminta kepada perwakilan kelompok tertentu untuk menyajikan temuannya di depan kelas.

Penelitian ini dilakukan dengan menerapkan pendekatan kualitatif. Metode yang digunakan yakni analisis deskriptif. Metode ini menguraikan hasil penelitian dalam bentuk kata-kata secara terperinci dalam menggambarkan suatu keadaan yang benar-benar terjadi pada subjek penelitian yang diamati (Moleong, 2010).

Subjek penelitian yaitu dua orang mahasiswa yakni satu orang penyandang tuna rungu kategori ringan dan satu orang penyandang tuna wicara (gagap). Penelitian ini dilakukan untuk mendeskripsikan bagaimana motivasi dan kemandirian belajar mahasiswa pada mata kuliah belajar dan pembelajaran. Penelitian ini dilakukan pada jurusan Pendidikan Bahasa dan Sastra Indonesia, Fakultas Pendidikan dan Ilmu Keguruan, Universitas Musamus. Data diperoleh melalui wawancara, observasi mendalam serta dokumentasi. Data dianalisis secara kualitatif dengan reduksi data, penyajian data serta penarikan kesimpulan.

\section{HASIL DAN PEMBAHASAN}

Observasi awal menunjukkan mahasiswa tuna rungu dan tuna wicara cenderung menutup diri. Setelah diidentifikasi hal yang membuat mahasiswa cenderung menarik diri disebabkan oleh rasa kurang percaya diri dalam berkomunikasi dan bersosialisasi. Kesulitan tersebut menyurutkan motivasi serta kemandirian belajar mahasiswa. Upaya yang dilakukan dosen dalam mengatasi hambatan belajar tersebut dengan menerapkan model pembelajaran kooperatif tipe TTW.

Pada pelaksanaan pembelajaran, dosen selalu menyiapkan media berupa video disertai suara dan tulisan. Media tersebut digunakan untuk mempermudah seluruh mahasiswa, terutama mahasiswa tuna rungu dan tuna wicara dalam memahami materi. Setiap pelaksanaan pembelajaran, mahasiswa dibagi menjadi beberapa kelompok secara heterogen. Mahasiswa tuna rungu dikelompokkan dengan mahasiswa normal, begitupun mahasiswa tuna wicara, dikelompokkan juga dengan mahasiswa normal. Hal tersebut bertujuan untuk membiasakan mahasiswa saling berinteraksi dan berdiskusi bersama tanpa memandang perbedaan. Pengelompokkan seperti itu membuat mahasiswa tuna rungu dan tuna wicara tidak merasa terasingkan.

Mahasiswa tuna rungu di kelas ini termasuk kategori tuna rungu ringan. Pada kategori ini ia masih mampu berkomunikasi secara verbal dengan tatap muka dan volume suara lawan bicara harus sedikit lebih tinggi. Pada pertemuan pertama menggunakan model TTW, mahasiswa terlihat masih kurang percaya diri. Kegiatan pembelajaran secara berkelompok membantu mahasiswa tuna rungu dalam memahami materi. Penjelasan dari video yang sudah dilengkapi audio serta tulisan, diperdalam oleh diskusi antar teman secara langsung. Selain daripada materi lebih mudah dipahami, mahasiswa tuna rungu menjadi lebih percaya diri dalam berinteraksi dengan teman lain. 


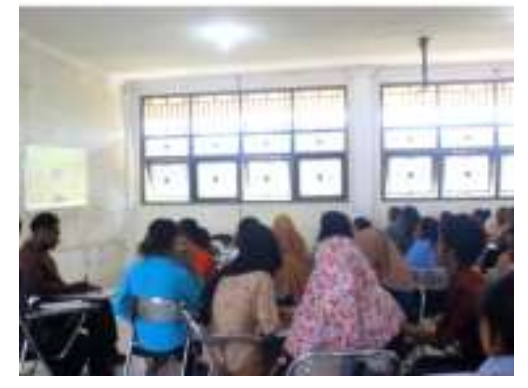

Gambar 1. Menampilkan Video Pembelajaran

Sama halnya dengan mahasiswa tuna rungu, mahasiswa tuna wicara juga mengalami hal yang tidak jauh berbeda. Mahasiswa tuna wicara di kelas ini termasuk kategori gagap. Ujaran lisan yang diucapkan terdengar kurang jelas dan terbata-bata, sering terjadi pengulangan kata. Namun jika dibandingkan dengan mahasiswa tuna rungu, mahasiswa ini lebih cepat bersosialisasi. Meskipun masih tampak malu-malu, namun ia terlihat mau berbincang dengan teman satu kelompok.

Pada tahap berbicara, mahasiswa tuna rungu dan tuna wicara sama-sama diberikan kesempatan mempresentasikan materi di depan kelas. Perlu waktu yang cukup lama dalam menunggu kesiapan mahasiswa tuna rungu dan tuna wicara untuk berbicara di depan kelas. Penyampaian materi masih terbata-bata, volume suara sangat kecil sehingga tidak jelas terdengar. Mahasiswa terlihat belum percaya diri. Mengatasi hal tersebut, audience memberikan penguatan dengan cara memberikan tepuk tangan dan pujian terhadap mahasiswa tuna rungu dan tuna wicara yang sudah berani tampil di depan kelas.

Pertemuan-pertemuan selanjutnya, mahasiswa terlihat sudah mulai tahu cara belajar di kelas dengan model TTW. Kegiatan pembelajaran yang didesain menarik telah berhasil memotivasi mahasiswa untuk ikut berperan aktif didalam perkuliahan. Meskipun dalam hal berkomunikasi masih terlihat kurang percaya diri, suara terbata-bata dan kurang jelas, namun terlihat bahwa motivasi dan kemandirian belajar sudah berkembang.

Motivasi belajar meningkat dilihat dari beberapa aspek diantaranya tekun dalam mengerjakan tugas, ulet dalam menghadapi kesulitan, senang berdiskusi dan berinisiatif dalam kegiatan perkuliahan. Mahasiswa tuna wicara menunjukkan peningkatan motivasi belajar yang lebih tinggi dibandingkan dengan mahasiswa tuna rungu. Mahasiswa tuna wicara sudah lebih aktif dalam kegiatan perkuliahan. Ia lebih sering ikut berpartisipasi aktif dalam diskusi kelompok. Mahasiswa tuna wicara ini juga selalu ikut mencari solusi atas permasalahan yang dihadapi terkait materi yang sedang dibahas.
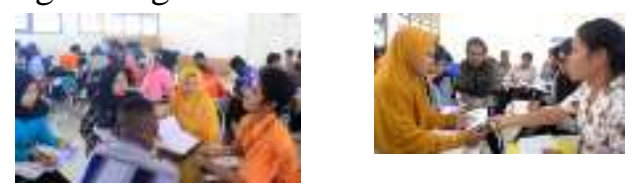

\section{Gambar 3. Proses Diskusi}

Sedikit berbeda dengan mahasiswa tuna wicara, mahasiswa tuna rungu masih kurang aktif berpartisipasi dalam kegiatan diskusi kelompok. Ia semangat dan bersedia terlibat dalam pembagian kelompok dan kegiatan diskusi. Hanya saja pada kegiatan diskusi, lebih banyak diam. Pada saatnya presentasi, mahasiswa tuna rungu masih memerlukan waktu yang lama sebelum akhirnya berani berbicara di depan kelas. Mengatasi hal tersebut, dosen memberikan penguatan berupa bimbingan belajar. Bimbingan yang diberikan menguatkan pemahaman akan materi sehingga mahasiswa lebih percaya diri. Pada akhirnya mahasiswa tuna rungu menunjukkan partisipasi aktif dalam perkuliahan. 


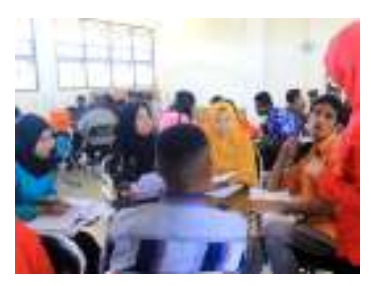

Gambar 4. Bimbingan Saat Diskusi

Adapun kemandirian belajar meningkat dinilai dari beberapa aspek diantaranya mampu mengelola strategi belajar, mampu mengatur waktu belajar, mampu mengatasi kesulitan memahami materi, dapat memilih sumber belajar yang sesuai termasuk rekan diskusi, adanya interaksi antar mahasiswa (Tahar, dkk. 2006: 95). Kemandirian mahasiswa tuna rungu cenderung baik. Hal tersebut ditunjukkan dengan kesediaan mahasiswa untuk bergabung bersama kelompok dan mengikuti diskusi kelompok. Meskipun partisipasi dalam diskusi masih rendah, tetapi sudah muncul kemandirian mahasiswa dalam mengikuti perkuliahan. Mahasiswa mampu mengelola waktu belajar cukup baik dengan fokus perhatian yang baik terhadap penyampaian materi. Mahasiswa sudah mau ikut serta dalam mencari solusi dari tugas yang dibebankan padanya dan pada kelompok meskipun masih belum maksimal. Mahasiswa juga terlihat sangat terbantu dengan media yang digunakan dosen karena ia bisa membaca materi dari apa yang dipaparkan dalam video.

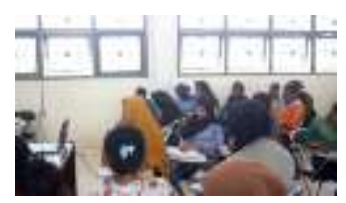

Gambar 5. Mahasiswa Membuat Catatan Kecil

Kemandirian mahasiswa tuna wicara juga sudah cenderung baik dengan ditunjukkannya perilaku aktif berpartisipasi dalam kegiatan perkuliahan. Mahasiswa terlihat mencatat hal-hal penting terkait dengan materi yang sedang dibahas. Ia juga cukup aktif dalam berdiskusi mencari solusi dari tugas yang diberikan. Penggunaan waktu belajar di kelas sudah cukup baik dengan tidak menunjukkan sikap diam saja tetapi mencatat hal-hal yang dianggap penting serta ikut berperan dalam kelompok. Mahasiswa tuna wicara sudah terlihat mandiri dalam mengerjakan tugas yang diberikan. Hal ini jga terlihat dari hasil wawancara yang diberikan kepada MBK setelah pembelajaran berakhir.

Adapun manfaat setelah dilakukan penelitian ini terhadap mahasiswa berkebutuhan khusus (MBK) yaitu:

1. MBK dapat berinteraksi dan berkomunikasi dengan baik bersama mahasiswa umum

2. Tumbuhnya rasa percaya diri dari MBK untuk berbaur dengan lingkungan sekitar

3. Meningkatnya kemandirian belajar MBK karena mahasiswa dapat lebih memahami materi dengan melihat kembali tayangan materi pembelajaran yang ada di video yang diberikan

4. Meningkatkan motivasi belajar MBK karena materi yang diberikan menggunakan bantuan media video pembelajaran animasi yang menarik

5. Mahasiswa dengan disable tunarungu dapat belajar dan memahami materi dengan melihat tayangan yang berupa gambar dan tulisan

6. Mahasiswa dengan disable tunanetra dapat belajar dan memahami materi dengan mendengarkan materi yang disampaikan

7. Mahasiswa dengan disable tunawicara dan tunadaksa dapat belajar dan memahami materi dengan melihat tayangan yang berupa gambar dan tulisan serta mendengarkan materi yang disampaikan 


\section{SIMPULAN}

Model pembelajaran kooperatif tipe Think Talk and Write (TTW) berbantukan media video membantu mahasiswa meningkatkan motivasi dan kemandirian belajar. Kegiatan diskusi dapat membantu mahasiswa dalam berkomunikasi dan bersosialisasi di kelas. Motivasi serta kemandirian mahasiswa terlihat meningkat dari pembelajaran ke pembelajaran selanjutnya.

Mahasiswa tuna rungu menunjukkan motivasi dan kemandirian belajar yang baik dalam mengikuti perkuliahan. Motivasi belajar mahasiswa meningkat dengan menunjukkan sikap yang cukup tekun dalam mengerjakan tugas. Tugas yang diberikan sudah dikerjakan meskipun hasilnya belum maksimal. Namun begitu, ia sudah menunjukkan kuletannya dalam menghadapi kesulitan. Mahasiswa masih belum menunjukkan partisipasi aktif dalam berdiskusi, masih terlihat malu-malu saat berdiskusi. Inisiatif berbicara dalam kegiatan perkuliahan sudah muncul meskipun kualitasnya masih harus ditingkatkan. Kesulitan dihadapi karena kurang dengar yang ia alami sehingga perlu adanya upaya terapi atau pengobatan jika memungkinkan dari ahli medis atau terapis.

Mahasiswa tuna wicara terlihat lebih cepat bersosialisasi dengan teman lain dibandingkan dengan mahasiswa tuna rungu. Mahasiswa tuna wicara tidak mengalami hambatan dalam pendengarannya sehingga pemerolehan kata serta pemahaman atas ujaran-ujaran dari mahasiswa lain maupun dosen lebih baik. Hanya saja, kemampuannya dalam mengutarakan kalimat dengan bahasa yang jelas masih sulit dilakukan. Mahasiswa tuna wicara masih terdengar gagap ketika berbicara. Tetapi kemampuannya dalam bersosialisasi dengan mahasiswa lain teramati telah meningkatkan motivasi belajar mahasiswa tersebut. Mahasiswa tuna wicara lebih tekun dalam mengerjakan tugas baik secara individu maupun kelompok. Keuletannya dalam menghadapi kesulitan dan tugas-tugas membantunya dalam meningkatkan hasil belajar. Mahasiswa terlihat senang berdiskusi dan berinisiatif dalam kegiatan perkuliahan.

Hasil penelitian menunjukkan bahwa kemandirian dan motivasi belajar mahasiswa cenderung baik dengan adanya peran aktif guru dalam mengaplikasikan model pembelajaran yang sesuai. Kesulitan komunikasi yang ada diantara mahasiswa di kelas berhasil diatasi dengan peran aktif seluruh mahasiswa dalam bekerja bersama dalam kelompok diskusi.

\section{DAFTAR RUJUKAN}

Anassyah, Nurvida \& Shodiq, M. 2016. Jurnal P3LB. Vol. 3 No. 2. p. 140147.

Asy'ari. 2016. Model Pembelajaran Think Tal Write (TTW) Berbasis Assessment For Learning (AFL) Melalui Penilaian Teman Sejawat Meningkatkan Kemandirian Belajar Siswa Kelas VIII. Math Didactic: Jurnal Pendidikan Matematika. Vol. 2, No. 2. p. 116-126.

Awaluddin. 2016. Komunikasi Non Verbal Antara Guru dan Siswa Tuna Wicara SLBN Somba OPU Kabupaten Gowa. Skripsi. Fakultas Dakwah dan Komunikasi. Universitas Islam Negeri Alauddin Makassar.

Gardinda, D. 2015. Pengantar Pendidikan Inklusi. Bandung: Refika Aditama.

Gavira, R.L., Morina, A., Aguilar, A.M., dan Rodriguez, V.H.P. 2016. Proposal For The Improvement Of University Classrooms : The 
Perspective Of Students With Disabilities. Procedia-Social and Behavioral Sciences 228. p. 175-182.

Juniardi, M.A., Parmiti, D.P., dan Dibia, I.K. 2017. Pengaruh Model Pembelajaran TTW Berbantuan Media Video Terhadap Hasil Belajar IPA Kelas V SD. Jurnal Mimbar PGSD. Vol. 5, No. 2, p. 1-10.

Lestari, Fitri. 2015. Metode Guru BK dalam Mengatasi Problem Penyesuaian Diri Pada Anak Berkebutuhan Khusus. Inklusi. Vol. 2. No. 2. p. 273-298.

Lestari, Dwi Sri. 2016. Penyesuaian Sosial Pada Mahasiswa Tuli. Inklusi: Journal of Disability Studies. Vol. 3 No. 1. p. 103-134.

Mahmud, Idam. 2016. Aktivitas Komunikasi Penyandang Tuna Wicara di Sekolah Luar Biasa AlFajar Pangalengan Kabupaten Bandung. Skripsi. Fakultas Ilmu Sosial dan Ilmu Politik. Universitas Komputer Indonesia.

Moleong, L. J. 2010. Metode Penelitian Kualitatif. Bandung: Remaja Rosdakarya.

Purwanto, Heri. 1998. Pengantar Perilaku Manusia. Jakarta: EGC.

RI, Permenristekdikti Nomor 46. 2017. Pendidikan Khusus dan Pendidikan Layanan Khusus Di Perguruan Tinggi.

RI, UU Nomor 8. 2016. Penyandang Disabilitas.
Tahar, Irzan. dkk. 2006. Hubungan Kemandirian Belajar dan Hasil Belajar Pada Pendidikan Jarak Jauh. Jurnal Pendidikan Terbuka Dan Jarak Jauh. Vol. 7. No. 2. p. 91-101.

Wardani, IG. A. K., dkk. 2012. Pengantar Pendidikan Luar Biasa. Banten: Universitas Terbuka.

Wasito, Dian R, dkk. 2010. Penyesuaian Sosial Remaja Tuna Rungu yang Bersekolah di Sekolah Umum. Insan. Vol. 12. No. 3. p. 138-152. 